\title{
Development of New Electrode System for High Field Dielectric Properties Measurement Using Evaporated Polypropylene Thin Guard Film
}

\author{
Masayuki Fujii Member (Oshima National College of Maritime Technology, fujii@m.oshima-k.ac.jp) \\ Kazuyuki Tohyama Member (Numazu College of Technology, tohyama@ece.numazu-ct.ac.jp) \\ Tetsuro Tokoro Member (Gifu National College of Technology, tokoro@girfu-nct.ac.jp) \\ Yukio Mizuno Member (Nagoya Institute of Technology, mizuno@elecom.nitech.ac.jp) \\ Masayuki Nagao Member (Toyohashi University of Technology, nagao@tut.ac.jp) \\ Masamitsu Kosaki Member (Gifu National College of Technology, kosaki@gifu-nct.ac.jp)
}

Keywords : polypropylene, evaporated polypropylene, high-field dielectric properties, $\tan \delta$, AC dissipation current

Non-polar polymers such as polyethylene (PE) and polypropylene (PP) are widely used as very important electrical insulating and dielectric materials. They are used in the increasingly high $\mathrm{AC}$ electric field strength region approaching to the limit of electrical breakdown strength of the materials. Therefore the study of high-field dielectric property is very important in terms of understanding the AC breakdown mechanism of materials. A three-terminals electrode system with a guard film (new type electrode system) was developed in our laboratory for the precise measurement of high-field $\tan \delta$, where the guard film was used to reduce the disturbance of electric field around the edge of a main electrode. However, minute air sometimes steals between a sample film and the guard film. The air sometimes generates partial discharge in the high electric field region. Therefore, when the sample had minute air, the new type electrode system was limited under $100 \mathrm{kV}_{\mathrm{rms}} / \mathrm{mm}$ application that didn't reach to an intrinsic breakdown strength of the $30 \mu \mathrm{m}$-thick sample.

We tried to improve the new electrode system without minute air between a sample film and the guard film. We also tried to make very thin guard film to reduce the field disturbance at the edge of main electrode. In this paper a PP-guard film on a



High voltage electrode $(\phi 40 \mathrm{~mm})$

Fig. 1. New electrode system with guard film biaxially oriented polypropylene (BOPP) film was made by evaporation. This improvement of the electrode system using the evaporated PP-guard film was in success so that high-field dielectric properties of BOPP film could be measured up to near the intrinsic breakdown field of the sample.

The improved new electrode system using evaporated PP guard film enables the measurement of $\tan \delta$ in higher electric field region larger than $100 \mathrm{kV}_{\mathrm{rms}} / \mathrm{mm}$ with usual method, because there are no air void between sample film and guard film made by evaporated PP. Furthermore we could measure the $\tan \delta$ and the dissipation current till about $270 \mathrm{kV}_{\mathrm{rms}} / \mathrm{mm}$., with using fast rising $\mathrm{AC}$ ramp voltage application technique. In room temperature region $\tan \delta$ and dissipation current have a small electric field dependence and show no drastic change, except the quick increase just before breakdown. It is thought that the modified Pool-Frenkel effect dominates the high field AC loss mechanism till $250 \mathrm{kV}_{\mathrm{rms}} / \mathrm{mm}$ in room temperature region.



Fig. 2. Electric field dependence of tand till breakdown of BOPP film with improved new electrode system 


\section{蒸着ポリプロピレン薄膜をガードフィルムに用いた}

\section{高電界誘電特性測定用電極系の試作}

$\begin{array}{llll}\text { 正員 藤井 } & \text { 雅之* } & \text { 正員 遠山 } & \text { 和之** } \\ \text { 正 員 所 } & \text { 哲郎 } * * * & \text { 正 員 水野 } & \text { 幸男 } * * * * \\ \text { 正 員 長尾 } & \text { 雅行 } * * * * * & \text { 正 員 小㠃 } & \text { 正光*** }\end{array}$

\section{Development of New Electrode System for High Field Dielectric Properties Measurement Using Evaporated Polypropylene Thin Guard Film}

Masayuki Fujii*, Member, Kazuyuki Tohyama**, Member, Tetsuro Tokoro***, Member, Yukio Mizuno****, Member, Masayuki Nagao $* * * *$, Member, Masamitsu Kosaki***, Member

Non-polar polymers such as polyethylene (PE) and polypropylene (PP) are widely used as very important electrical insulating and dielectric materials. They are used in the increasingly high AC electric field strength region approaching to the limit of electrical breakdown strength of the materials. Therefore the study of high-field dielectric property is very important in terms of understanding the AC breakdown mechanism of materials. A three-terminals electrode system with a guard film (new type electrode system) was developed in our laboratory for the precise measurement of high-field tan $\delta$, where the guard film was used to reduce the disturbance of electric field around the edge of a main electrode.

However, minute air sometimes steals between a sample film and the guard film. The air sometimes generates partial discharge in the high electric field region. Therefore, when the sample had minute air, the new type electrode system was limited under $100 \mathrm{kV}_{\mathrm{rms}} / \mathrm{mm}$ application that didn't reach to an intrinsic breakdown strength of the $30 \mu \mathrm{m}$-thick sample. We tried to improve the new electrode system without minute air between a sample film and the guard film. We also tried to make very thin guard film to reduce the field disturbance at the edge of main electrode. In this paper a PP-guard film on a biaxially oriented polypropylene (BOPP) film was made by evaporation. This improvement of the electrode system using the evaporated PP-guard film was in success so that high-field dielectric properties of BOPP film could be measured up to near the intrinsic breakdown field of the sample.

キーワード : ポリプロピレン, 蒸着ポリプロピレン, 高電界誘電特性, $\tan \delta$, 交流損失電流

Key words : polypropylene, evaporated polypropylene, high-field dielectric properties, $\tan \delta, \mathrm{AC}$ dissipation current

\section{1. まえがき}

ポリエチレン（PE）やポリプロピレン（PP）等の無極性 高分子は，電力ケーブルの絶縁材料や電力用コンデンサの 誘電材料などとして, 商用周波数の交流高電界下で使用さ
れることが多い。それらの使用電界は近年の電力需要の増 大に伴い年々高くなりつつあることから，高分子材料の交 流高電界誘電特性に関する研究, 特に誘電損失発生機構の 解明は絶縁劣化診断, 絶縁破壊予知とも関連しており非常 に重要である。

\footnotetext{
* 大島商船高等専門学校

T742-2193 山口県大島郡周防大島町大字小松 1091-1

Oshima National College of Maritime Technology

1091-1, Komatsu, Suouoshima-cho, Oshima-gun, Yamaguchi $742-2193$

** 沼津工業高等専門学校

于410-8501 沼津市大岡 3600

Numazu National College of Technology

3600 Ooka, Numazu 410-8501

*** 岐阜工業高等専門学校

T501-0495 本巣市上真桑 2236-2
}

Gifu National College of Technology

2236-2, Kamimakuwa, Motosu 501-0495

*****名古屋工業大学

T466-8555 名古屋市昭和区御器所町

Nagoya Institute of Technology

Gokiso-cho, Showa-ku, Nagoya 466-8555

******豊橋技術科学大学

T441-8580 豊橋市天伯町雲雀ヶ丘 1-1

Toyohashi University of Technology

1-1, Hibarigaoka, Tenpaku-cho, Toyohashi 441-8085 
筆者らはこれまでに無極性高分子フィルムを主な対象と して, その誘電正接（ $\tan \delta ）$ や静電容量などの高電界誘電 特性の測定を行ってきた ${ }^{(1)(2)}$ 。特に $\tan \delta$ は劣化診断の一指 標として測定されることが多いので，広く一般に用いられ ている測定手法より高い印加電界まで測定可能な手法の開 発を進めてきた。その一環として, 筆者らの研究グループ は高分子フィルムの高電界誘電特性測定用として拡張ガー ド電極付き電極系（新電極系）を開発してきた ${ }^{(3)}$ 。平行平板 電極系を改良した拡張ガード電極付き電極系は, ガードフ イルムを用いてガード電極が主電極を覆い, 主電極端部で の電気力線の乱れが誘電特性に及ぼす影響をできるだけ排 除している。さらに交流高電界印加時において問題となる 気中部分放電の発生を抑制する目的で，試料全体にエポキ シ樹脂モールドを施している。このような電極系の改良に より $\tan \delta$ および静電容量を高電界まで精度よく測定するこ とが可能となった ${ }^{(3)(4)}$ 。

しかしながら，ガードフィルムを供試フィルムに貼り合 わせる際に，その間にわずかであるが空気が入り込んでし まうことがあり，この空気が主電極端部に残ると部分放電 の発生原因となる。また, 電流比較型ブリッジの同調をと るのに数十秒を要することなどから, その測定可能電界は $30 \sim 40 \mu \mathrm{m}$ の試料厚に対して $100 \mathrm{kV} \mathrm{rms}_{\mathrm{rm}} / \mathrm{mm}$ 以下に限られてい た。端部の影響や長時間印加による材料劣化の影響を伴わ ない真性絶縁破壊に近い高電界まで高分子フィルムの誘電 特性を測定するためには, 電極系の更なる改良が望まれて いた。

そこで，ガードフィルムと供試フィルムの間に空気が入 り込むことを抑制するために, 蒸着ポリプロピレン薄膜を ガードフィルムの代替とした電極系 (蒸着 PP ガード薄膜電 極系）を試作した(5)。さらに，交流ランプ波を用いた新しい 測定手法(6)により二軸延伸ポリプロピレン (BOPP) フィル ムの真性絶縁破壊に近い交流高電界までの誘電特性測定を 試みたのでこれらについて報告する。

\section{2. 試料および実験方法}

〈2・1〉試料試料は図 1 に示寸拡張ガード電極付き 平行平板電極系である。供試フィルムには公称厚さ $30 \mu \mathrm{m}$ の 二軸延伸ポリプロピレン（BOPP）フィルム（東レ，トレフ アン-BO 使用，コンデンサ用フィルム）を使用した。この 供試フィルムに主電極, ガード電極, および高電圧電極と して金を両面に真空蒸着し，平行平板同心円状 3 端子電極 系を形成した。ガードフィルムは供試フィルムと同じフィ ルムを貼り付けたものと, 蒸着ポリプロピレン薄膜形成に よるものの 2 種類の方法により形成した。ガードフィルム 上には，さらに拡張ガード電極として金を真空蒸着してあ る（図 1)。各電極に導電性ペーストにより, リード線を取 り付けた後, 交流高電界下での気中部分放電を抑制するた めにエポキシ樹脂で全体をモールドした。モールド用エポ キシ樹脂は, 旭電化工業製のアデカレジンで, 主剤 (EP-4100) と硬化剂（EH-531）を 100 対 60 の重量比で混合

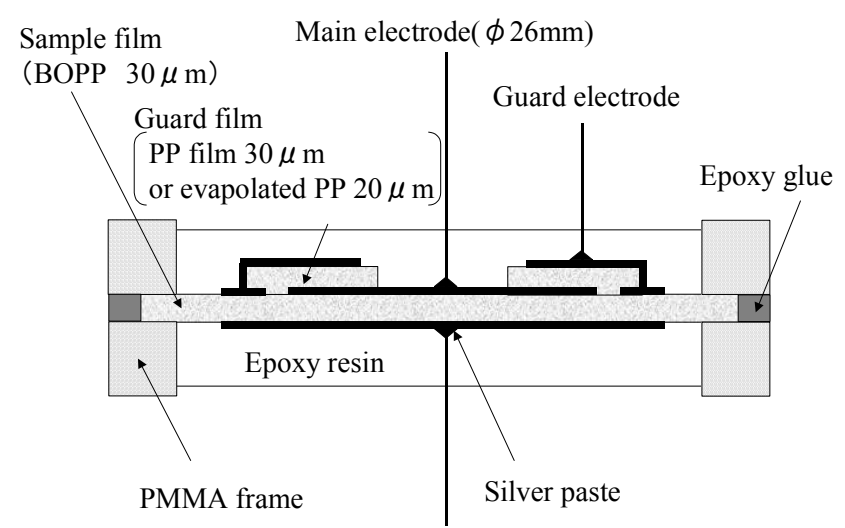

High voltage electrode $(\phi 40 \mathrm{~mm})$

図 1 試料形状

Fig. 1. Electrode system with guard film.

し, $30^{\circ} \mathrm{C}$ で 30 分脱気処理してボイドを除去した。室温のみ で測定する電極系は室温で十分硬化し, 高温まで測定する 電極系はそれを更に $80^{\circ} \mathrm{C}$ で熱処理した後硬化した。

$\langle 2 \cdot 2\rangle$ 蒸着ポリプロピレンガード薄膜の作成 真空 蒸着法により BOPP フィルムの主電極側に PP 蒸着を施し, ガード薄膜を形成した。約 20 粒の PP ペレット（三菱油化 製 MA3）を試験管に入れ，ニクロム線を熱源として温度 を $300^{\circ} \mathrm{C}$ まで約 1 時間かけて徐々に上げた。沸騰した PP の 状態が安定するまで約 2 時間待ち, その後シャッターを開 いた。さらに約 2 時間の蒸着を行い, $20 \mu \mathrm{m}$ の蒸着 PP 薄膜

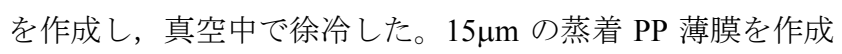
する際も同様の手順で行ったが, 蒸着時間は 1 時間半とし た。したがって, 蒸着レートは $10 \mu \mathrm{m} / \mathrm{hour}$ ということにな る。溶融 PP 面から供試フィルムまでの距離は約 $15 \mathrm{~cm}$, 真 空度は $1.5 \times 10^{-3} \mathrm{~Pa}$ 程度である。また, $300^{\circ} \mathrm{C}$ より低い温度 では $15 \mathrm{~cm}$ の高さまでPP が均一に飛ばず，この距離を短く することは, 試料面への熱源からの熱的劣化が問題となっ た。

図 2 に蒸着 PP ガード薄膜表面の SEM 解析結果を示す。 図 2(a)は厚さ $20 \mu \mathrm{m}$ の蒸着 PP 薄膜表面を解析したもので, 良好な絶縁膜が形成されている。図 2(b)は厚さ $15 \mu \mathrm{m}$ の蒸着 PP 薄膜表面を解析したものであるが, 主電極端部では絶縁 膜で完全に覆われていない箇所があることが分かる。ガー ドフィルムの厚さをより薄くすることで, 主電極端部での 電気力線の乱れはさらに抑制することができる(6)。しかしな がら, 本実験に用いた蒸着装置では, 蒸着 PP 薄膜を $20 \mu \mathrm{m}$ より薄くした場合に良好な絶縁膜が得られないことから， 以後, 蒸着 PP ガード薄膜の厚さとしては $20 \mu \mathrm{m}$ を用いるこ ととした。

さらに, 蒸着熱源の温度が高く, 飛ばされた PP が供試〉 イルムへ及ぼす熱的な悪影響が懸念されることから, FT-IR 解析を行った。図 3(a)は PP 蒸着前の供試フィルム $30 \mu \mathrm{m}$ の 解析結果, 図 3(b)は供試フィルムに厚さ $20 \mu \mathrm{m}$ の PP 蒸着を 行った後の解析結果である。解析に用いた試料の厚さが PP 蒸着の有無によって異なるため, $3000 \mathrm{~cm}^{-1}$ 付近の吸光度の 


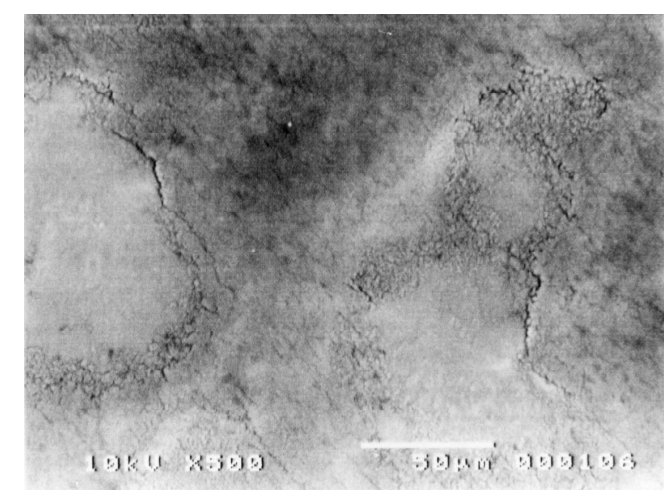

(a) Good insulation surface of evaporated polypropylene guard film

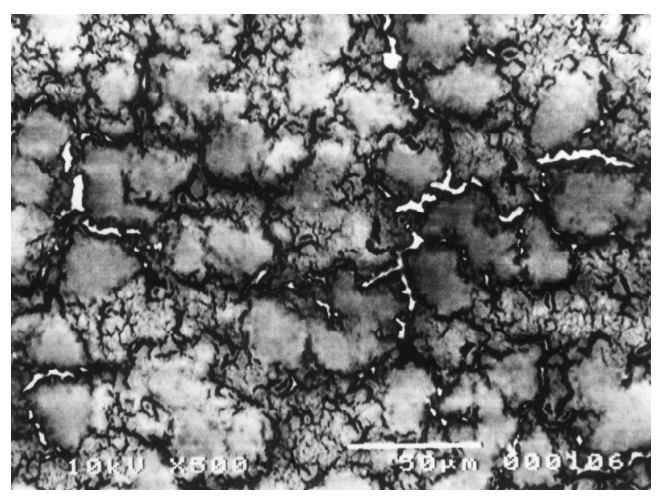

(b) Bad insulation surface of evaporated polypropylene guard film

図 2 蒸着 PP ガード薄膜表面の SEM 解析

Fig. 2. SEM analysis of the surface of evaporated PP guard film.

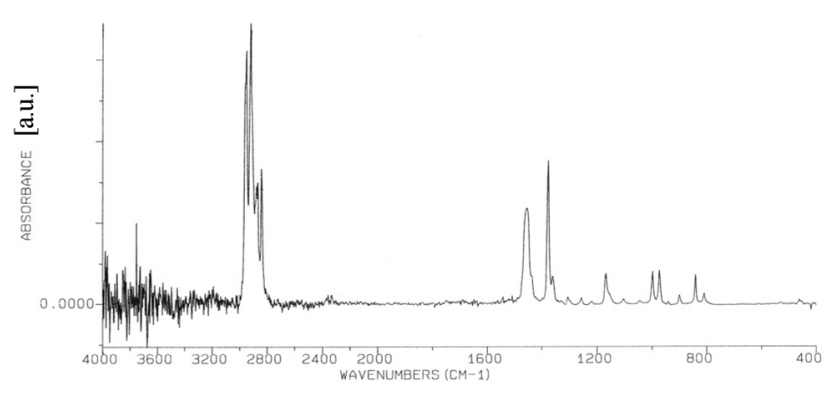

(a) FT-IR analysis of BOPP film of normal thickness of $30 \mu \mathrm{m}$

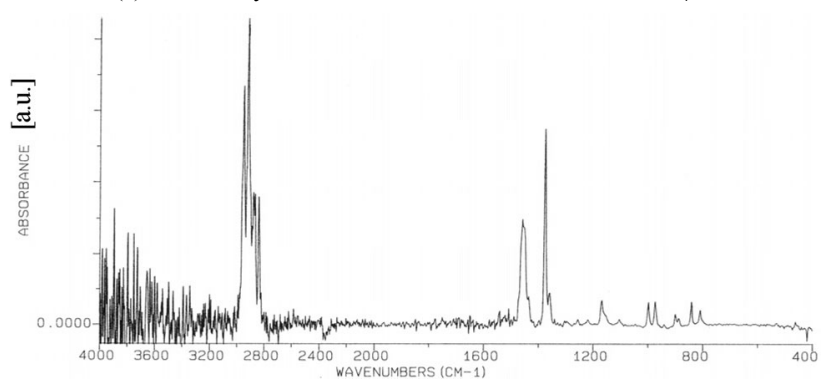

(b) FT-IR analysis of BOPP film with $20 \mu$ m thick evaporated PP

図 3 試料の FT-IR 解析

Fig. 3. FT-IR analysis of the samples.

ピークが等しくなる様に, 縦軸に任意単位[a.u.]を用いて比 較している。その結果, PP 蒸着の前と後では吸光帯に変化 が見られなかった。なお, 蒸着 PP 薄膜は本実験を遂行する

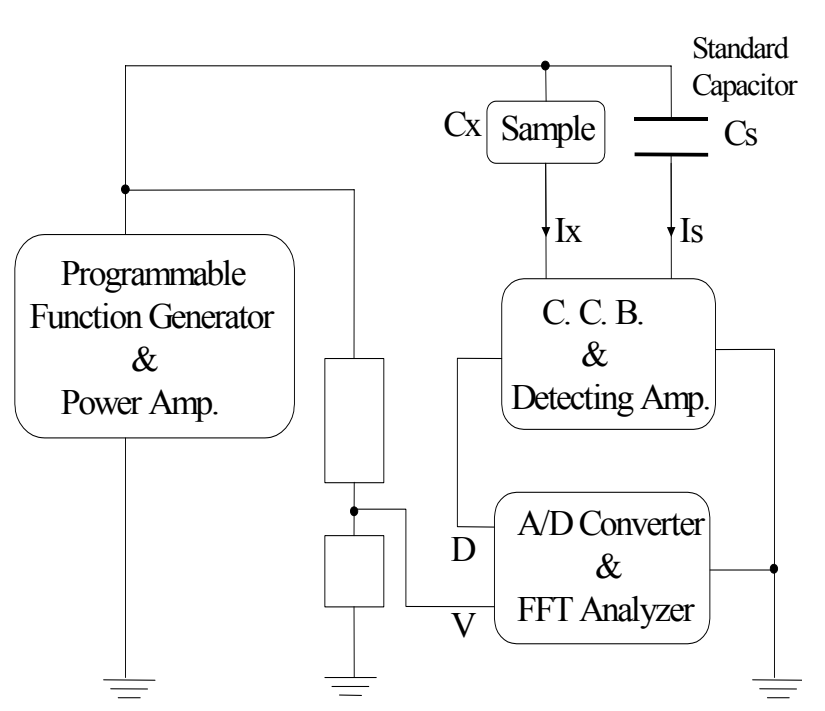

図 4 高電界誘電特性測定システムの概略

Fig. 4. Outline of the system for measuring high-field dielectric properties.

のに十分な絶縁特性を有していることを確認している。

$\langle 2 \cdot 3\rangle$ 高電界誘電特性測定回路 高電界誘電特性測 定回路の概略を図 4 に示す。プログラマブル波形発生器 (1731S : NF Elec. Ins.)によって 3 連交流ランプ電圧などの印 加電圧波形を発生し, 電力アンプ（TA-120 : NF Elec. Ins.) とトランスによって増幅・昇圧した。この電圧を恒温槽中 に保持された試料に印加し, 電流比較形ブリッジ（CCB： Current Comparator Bridge, 1210-A, Sohshin Elec.) によって $\tan \delta$ と静電容量を測定した。以下, 本論文では印加電界は すべて実効值である。

また，交流損失電流もこのブリッジシステムによって測 定した。印加電圧波形 (V), 試料を流れる電流のうち充電 電流成分のみを $\mathrm{CCB}$ でほぼキャンセルしたブリッジの不平

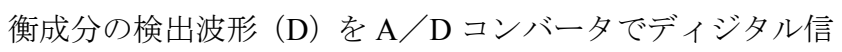
号に変換する。それらのデータをコンピュータに保存し, FFT 波形解析することによって非線形応答を含む交流損失 電流を求めることができる。この波形記憶装置の分解能は 16bit, メモリ長は最大で 1000 kword, サンプリングレートは 通常 $50 \mu \mathrm{sec}$ である。検出波形 $\mathrm{D}$ は印加電圧波形 $\mathrm{V}$ と比較さ れ, 各 1 サイクルごとに分解される。FFT 波形解析プログ ラムを使って各周波数成分に分解され, このスペクトルデ 一タから $\tan \delta$, 損失電流, 容量成分の変化および非線形応 答を評価する。この測定システム全体の伝達関数は FFT 波 形解析プログラム中に反映されている。なお, 交流高電界 において試料となる高分子フィルムに絶縁破壊が発生して も，測定システムに影響が無いという特性を有している。

図 5 に交流ランプ電圧波形 $\mathrm{V}$ と検出波形 $\mathrm{D}$ を示す。交流 ランプ電圧は $0 \mathrm{~V}$ から最大電圧まで昇圧し, 最大電圧から $0 \mathrm{~V}$ に降圧するのにそれぞれ $1 \mathrm{sec}$ に設定した。また，交流ラ ンプ電圧印加を連続して 3 回繰り返しているが, その最大 電界はそれぞれ 200， 250， $300 \mathrm{kV}_{\mathrm{rms}} / \mathrm{mm}$ と変化するように 

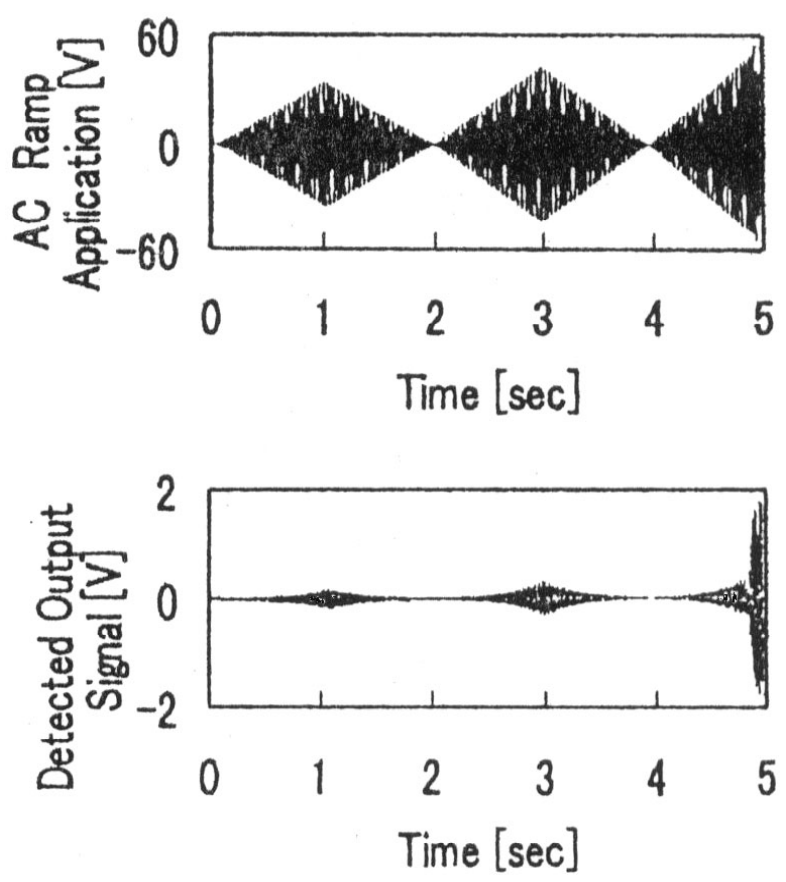

図 5 交流ランプ電圧と検出された試料の出力信号

Fig. 5. AC ramp voltage application and its detected output signal from the sample.

設定した。最大值が $300 \mathrm{kV}_{\mathrm{rms}} / \mathrm{mm}$ となる交流ランプ電界の ピーク值付近で絶縁破壊に至っており, 絶縁破壊直前に出 力波形 D が急増していることが分かる。

\section{3. 実験結果と考察}

〈3·1〉従来の測定手法による $\tan \delta$ の電界依存性

図 6 は室温における $\tan \delta$ の電界依存性を従来のブリッジ 同調による手法で測定した結果である。試料に交流 $50 \mathrm{~Hz}$ の 電圧を印加し, 電界が $10 \mathrm{kV}_{\mathrm{rms}} / \mathrm{mm}$ ステップとなるように上 昇した。各電界において約 $30 \mathrm{sec}$ 以内に手動で CCB の同調 をとり，試料が絶縁破壊するまで測定を続けた。

ガードフィルムを貼り付けた電極系は $80 \mathrm{kV}_{\mathrm{rms}} / \mathrm{mm}$ を超え ると部分放電が発生し, CCB のバランスが不安定になり， $110 \mathrm{kV}_{\mathrm{rms}} / \mathrm{mm}$ に上昇したとき絶縁破壊に至った。これに対し 改良した電極系は $140 \mathrm{kV}_{\mathrm{rms}} / \mathrm{mm}$ においても部分放電の発生 が認められず，良好に測定を継続することができ， $150 \mathrm{kV}_{\mathrm{rms}} / \mathrm{mm}$ に上昇したときに絶縁破壊に至った。

どちらの電極系で測定された $\tan \delta$ もほぼ同じ值を示して おり，部分放電が発生しない限りガードフィルムを貼り付 けた電極系でも正確な $\tan \delta$ 測定ができることを示してい る。また，いずれの電極系でも絶縁破壊直前において $\tan \delta$ の急増は観測されなかった。

ガードフィルムを貼り付けた電極系は，供試フィルムと 貼り付けたガードフィルムの間にわずかな空気が入り込む 可能性があり, 高電界下で部分放電が発生するため, 比較 的低い電界で絶縁破壊に至ったと考えられる。これに対し, 蒸着 PP ガード薄膜電極系は, 真空蒸着法によってガード薄 膜を作成するため供試フィルムとの間に空気が存在せず,

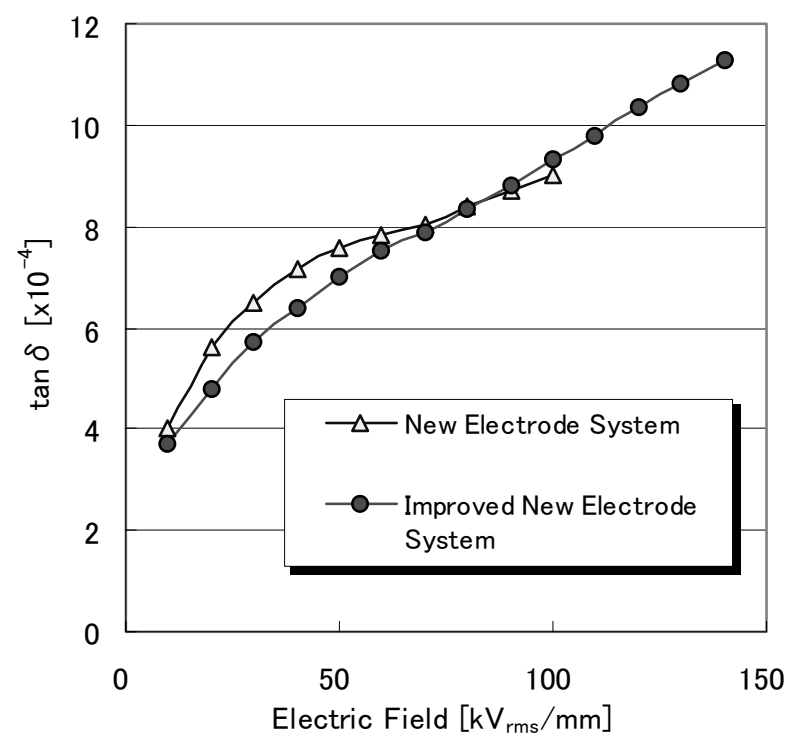

図 6 拡張ガード電極付き電極系と改良を加えた 電極系における $\tan \delta$ の電界依存性の比較

Fig. 6. Comparison of electric field dependence of $\tan \delta$ between the new electrode system and the improved new electrode system.

部分放電が発生しにくいため, より高電界まで $\tan \delta$ の測定 が可能になったと思われる。

どちらの電極系も主電極端部に破壊孔が認められたこと から, 破壊の原因は主電極端部の僅かな電界集中に起因し ていると思われる。従って, 材料の真性絶縁破壊までの高 電界誘電特性を測定するためには, 蒸着電極の diffused edge を含めた電界集中の緩和などが必要である ${ }^{(6)}$ 。

〈3·2〉交流ランプ波を用いた新しい測定手法から求め た $\tan \delta$ の電界依存性室温において試料の真性絶縁破 壊に近い電界領域まで $\tan \delta$ の電界依存性を測定するために 図 5 の交流ランプ電圧を印加した。従来の $\tan \delta$ の測定手法 は一定の電界で CCB の同調を手動でとるのに数十秒を必要 とする。そのため試料に高電圧を印加する時間が長くなり, 改良された電極系を用いても $140 \mathrm{kV}_{\mathrm{rms}} / \mathrm{mm}$ までしか測定が できなかった。しかし, 交流ランプ電圧を印加する手法は 測定に必要な時間を著しく短縮することができ, さらに高 電界まで交流高電界誘電特性測定が可能になった。

図 7 は交流ランプ電圧印加時の検出波形 D から FFT 波形 解析により算出した $\tan \delta$ の電界依存性を示している。試料 の BOPP フィルムが絶縁破壊に至ったのは 3 番目の交流ラ ンプ波上昇時であり, 破壊孔は主電極端部に見られた。室 温において $\tan \delta$ は交流ランプ電界の上昇とともに緩やかに 上昇していき, 約 $270 \mathrm{kV}_{\mathrm{rms}} / \mathrm{mm}$ で急激な増加をともなって 絶縁破壊に至っている。絶縁破壊直前における検出波形 D の増加ほど $\tan \delta$ が増加していないのは, $\tan \delta$ は基本波成分 $(50 \mathrm{~Hz})$ のみから算出されているためである。検出波形 D に は充電電流の不平衡成分や交流ランプ波の非線形性に伴う 基本波の高調波成分などが含まれており，これらが絶縁破 


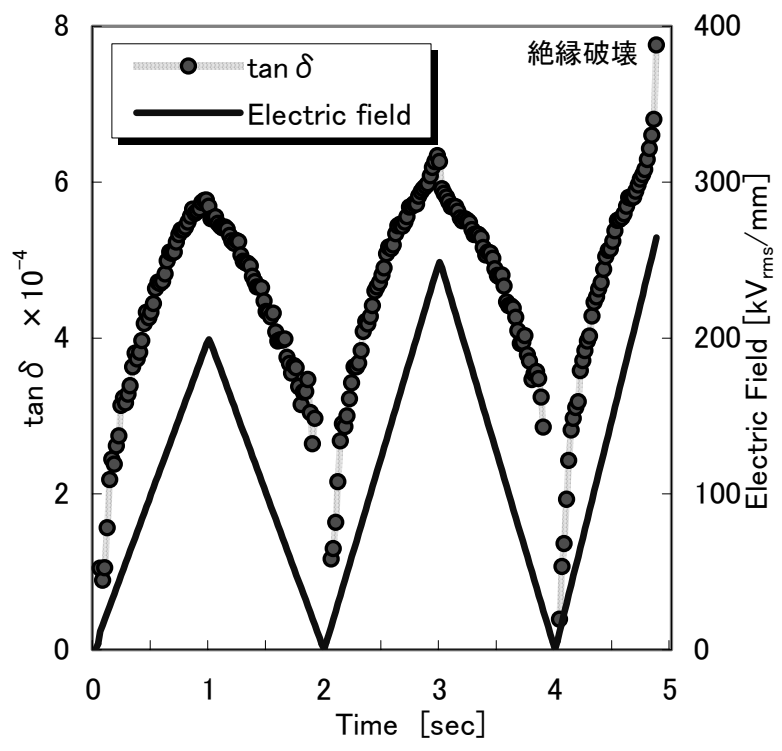

図 7 改良された電極系において BOPPフィルムが 絶縁破壊に至るまでの $\tan \delta$ の電界依存性

Fig. 7. Electric field dependence of $\tan \delta$ untill breakdown of BOPP film with the improved new electrode system.

壊直前の急増に影響していると考えられる。

今回の実験に用いた短時間測定手法は，約 2 秒の測定時

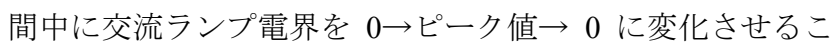
とができるので, 試料にかかる電界ストレスが極めて短時 間であり，高電界の長時間印加に伴う $\tan \delta$ の時間依存性 ${ }^{(7)}$ による影響を受けることなく誘電特性の測定が可能であ る。従って, 時間依存性が大きく, CCB の同調測定が困難 であった高温高電界領域においても，短時間で高電界まで 誘電特性が測定可能となった。

図 8 は改良された電極系を用いて測定した室温と $80^{\circ} \mathrm{C}$ おける $\tan \delta$ の電界依存性である。室温の $50 \mathrm{kV}_{\mathrm{rms}} / \mathrm{mm}$ 以下 の電界領域において, 交流ランプ電界上昇時に比べて下降 時の $\tan \delta$ の方が大きい值を示している。これは交流ランプ 電界上昇時に励起または注入されたキャリアが下降時に損 失に寄与したと考えられる。

室温付近と高温高電界側では，それぞれ別の損失機構が 支配的であるとした場合, $\tan \delta$ の電界による増分 $\Delta \tan \delta$ は 以下の（1）式で表される(2)。

$$
\Delta \tan \delta=\tan \delta_{\mathrm{PF}}+\sigma_{\mathrm{X}} / \omega \varepsilon
$$

ここで, $\tan \delta_{\mathrm{PF}}$ は室温領域に見られる電界の上昇にとも なって緩やかに上昇する成分であり, 修正プール・フレン ケル機構による損失である。 $\tan \delta_{\mathrm{PF}}$ は商用周波数領域でほ とんど周波数依存性を示さない。また， $\sigma_{\mathrm{X}} / \omega \varepsilon$ は高温高 電界領域で支配的となる温度および電界に大きく依存性を 示寸成分であり, 直流電界印加時にも観測される導電損失 を表している。 $\sigma_{\mathrm{x}}$ もまた周波数依存性をほとんど示さな い。今回の測定においても, 高温領域になると上式の右辺 第二項の影響が顕著に現れ， $\tan \delta$ の電界依存性が顕著とな

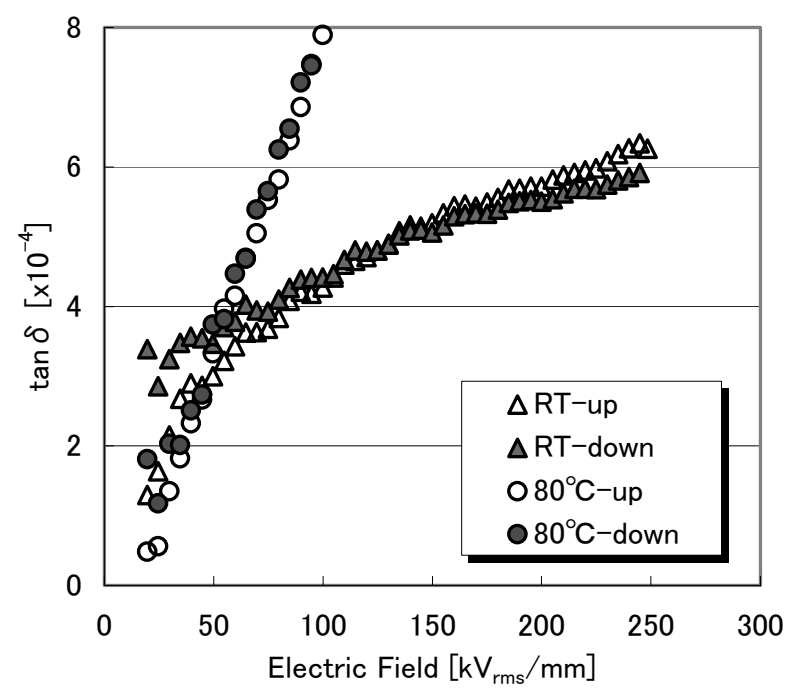

図 8 改良された電極系を用いた室温と $80^{\circ} \mathrm{C}$ における $\tan \delta$ の電界依存性の比較

Fig. 8. The comparison of $\tan \delta$ of BOPP film between at room temperature and at $80^{\circ} \mathrm{C}$ with the improved new electrode system.

ったと思われる。

現在, 交流損失電流波形および充電電流の不平衡成分に 関する研究も進めている。印加電界の波形が正弦波であっ ても, 交流高電界領域における交流損失電流波形には非線 形性が見られる ${ }^{(8) \sim(10)}$ 。このような結果は, この測定システ ムだけに見られる特異な現象ではなく, 電流比較形ブリッ ジを使わない測定システムにおいても観測されることが分 かっている(11)。また，交流損失電流が非線形性を示し始め る電界と電界発光が観測される電界にはきわめて良い相関 があることも報告されている(12)(13)。交流損失電流波形の非 線形性には, 電極界面に形成される空間電荷の影響と考え られるものもあるが, 交流 1 周期における外部印加電界の 最大で交流損失電流が最大とならないことが分かってお り, 電界上昇率 $(\mathrm{dE}(\mathrm{t}) / \mathrm{dt})$ の影響についてもさらに検討が 必要と考えられている(11)。

\section{4. まとめ}

蒸着ポリプロピレンをガードフィルムの代替として拡張 ガード電極付き電極系を改良し, 蒸着ポリプロピレンガー ドフィルム電極系を試作した。さらに, 交流ランプ波を用 いた新しい測定手法により, 二軸延伸ポリプロピレン (BOPP) フィルムの交流高電界誘電特性をより高電界まで 測定可能とした。以下に本論文の内容を要約する。

(1) FT-IR 解析の結果, ポリプロピレン蒸着を施す前と 後でポリプロピレンフィルムの吸収スペクトルに変化が見 受けられなかったことから, 蒸着ポリプロピレン薄膜の付 着が供試フィルムに及ぼす影響はないと考えられた。

(2) 蒸着ポリプロピレンによりガード薄膜を形成した 電極系はガードフィルムを貼り付けた電極系よりも高電界 
まで誘電特性の測定が可能になった。

（3）交流ランプ波を用いた新しい測定手法により，二軸 延伸ポリプロピレン（BOPP）フィルムの真性絶縁破壊に近 い交流高電界まで誘電特性の測定が可能になった。

(4) 室温領域においても従来のブリッジ同調測定では 観測できなかった大きな電界依存性を有する導電損失成分 の影響による $\tan \delta$ の急増を BOPP フィルムにおいて $250 \mathrm{kV}_{\mathrm{rms}} / \mathrm{mm}$ より高い電界領域で観測できた。

蒸着 PP ガード薄膜を用いることにより, 室温領域から高 温領域に至る誘電特性の測定を, より高電界まで可能とし た。今後, 交流高電界下におけるフィルム試料中への空間 電荷層の形成が高電界誘電特性に及ぼす影響などについ て, 詳細な測定と考察を進める。

高分子蒸着法は金属のような融点の高い基板材料に対し ては大変有効な絶縁手法である。しかし，高分子蒸着を高 分子材料に対して行うことは一般に非常に困難である。特 にポリエチレンのような融点の低い材料に対しては高分子 蒸着の手法に更なる改良が必要である。そのため, ポリエ チレンの交流高電界誘電特性を測定するために供試フィル ムとガードフィルムを熱融着する方法などの検討も進めて いる(14)。

最後にポリプロピレンの蒸着法について御教示頂きまし た愛知工業大学 落合教授, FT-IR 解析に御協力頂きました 電線総合技術センターの関係各位に感謝致します。

(平成 17 年 6 月 28 日受付, 平成 17 年 12 月 19 日再受付)

\section{文献}

(1) 所 哲郎・清水秀己・長尾雅行・小㠃正光:「ポリエチレンフィルム の高電界誘電特性」, 電学論 A, Vol.105-A, No.9, pp.463-470 (1985-9)

(2) 所 哲郎・遠山和之・田草川守・長尾雅行・小㠃正光:「高温領域に おけるポリプロピレンフィルムの高電界誘電特性」, 電学論 $\mathrm{A}$, Vol.110-A, No.6, pp.101-107 (1992-6)

(3) 遠山和之・所 哲郎・長尾雅行・小㠃正光:「高温領域における無極 性高分子フィルムの高電界誘電特性測定用新電極系の開発」, 電学論 A, Vol.109-A, No.7, pp.311-317 (1989-7)

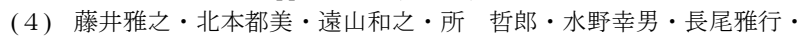
小嵪正光 : 「蒸着ポリプロピレンガードフィルムによる高電界 $\tan \delta$ 測定用電極系の高電圧化」, 平成 4 年度電気関係学会 東海支部連合 大会, No.263 (1989)

（5）所 哲郎・遠山和之・長尾雅行・小㠃正光：「高分子材料における微 小交流損失電流波形観測手法の開発」, 第 24 回 電気絶縁材料シンポ ジウム予稿VI-4 (1992)

（6）遠山和之・長尾雅行・小㠃正光:「高電界誘電特性測定用新電極系に よる静電容量の測定精度の向上」, 電学論 A, Vol.115-A, No.8, pp.751-755 (1995-8)

(7) 所 哲郎・中森昌治・長尾雅行・小㠃正光:「ポリエチレンフィルム の誘電正接の電界依存性および時間依存性」, 第 15 回電気絶縁材料 シンポジウム, P-4 (1982)

(8) S. Masuda, K. Tohyama, M. Nagao, T. Tokoro, and M. Kosaki : "Dissipation Current Waveform Observation of Polyethylene Film under AC High-Field", 2004 Annual Report Conference on Electrical Insulation and Dielectric Phenomena (2004CEIDP), pp.368-371 (2004) (in Japanese)

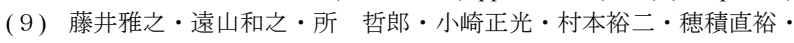
長尾雅行:「絶縁破壊に近い交流高電界領域における充電電流増加に 対する考察」, 電学論 A, Vol.121-A, No.6, pp.576-579 (2001-6)

(10) 藤井雅之 ・遠山和之 ・ 所 哲郎 $・$ 小崎正光・村本裕二・穂積直裕 $\cdot$ 長尾雅行: 「交流高電界下における高分子フィルムの静電容量変化に
もとづく空間電荷挙動の検討」, 電学論 A, Vol.121-A, No.7, pp.689-695 (2001-7)

(11) 遠山和之：「交流高電界下における電荷挙動」, 電気学会誘電・絶縁 材料研資, DEI-05-66, pp.47-52 (2005)

(12) K. Tohyama, S.S. Bamji, and A.T. Bulinski : "Simultaneous Measurement of Electroluminescence and Dissipation Current in Cable Insulation”, Proc. of the 7th International Conference on Properties and Applications of Dielectric Materials, S16-4, pp.1051-1054 (2003)

(13) K. Tohyama, M. Nagao, M. Kosaki, S. Bamji, and A. Bulinski : "High Field AC Conduction Mechanism in Non-polar Polymers", 1999 Annual Report Conference on Electrical Insulation and Dielectric Phenomena (1999CEIDP), pp.91-94 (1999) (in Japanese)

（14）道下昌彦・釣本崇夫・遠山和之・長尾雅行・小㠃正光 :「熱融着ガー ドフィルムによる高電界 $\tan \delta$ 測定用新電極系の試作 $\rfloor$ 平成 7 年電 気関係学会東海支部大会, No.265 (1995)

藤 井 雅之（正員） 1969 年 10 月 7 日生。1994 年 3 月豊

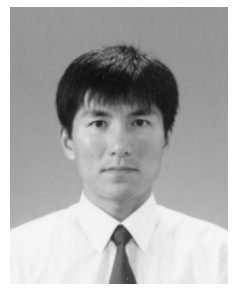
橋技術科学大学大学院工学研究科電気・電子工 学専攻修士課程修了。同年 4 月大島商船高等専 門学校電子機械工学科助手, 2003 年 4 月同講 師, 2006 年 4 月同助教授, 現在に至る。この間 に 2001 年 3 月豊橋技術科学大学大学院工学研 究科電子・情報工学専攻博士課程修了。博士 (工 学)。主として, 高分子絶縁材料の交流高電界 領域における誘電・絶縁特性に関する研究に従事。日本機械学会会 員。

遠山和之（正員） 1962 年 4 月 27 日生。1987 年 3 月豊 橋技術科学大学大学院工学研究科電気. 電子工

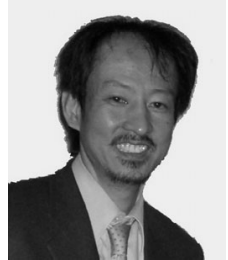
学専攻修士課程修了。同年 4 月沼津工業高等専 門学校電子制御工学科助手, 1995 年同講師, 1998 年同助教授, 2006 年同教授, 現在に至る。 博士 (工学)。1997 年 10 月〜1998 年 9 月およ び 2002 年 7 月〜9 月, National Research Council Canada にて S.S.Bamji 博士および A.T.Bulinski 博士のもとで在外研究 (高分子絶縁材料の電界発光現象に関する研 究)。主に高分子絶縁材料の高電界誘電特性・絶縁劣化現象に関寸 る研究に従事。1994 年電気学会優秀論文発表賞受賞。



（正員） 1957 年 8 月 14 日生。 1982 年 3 月 豊 橋技術科学大学大学院工学研究科電気・電子工 学専攻修士課程修了。同年 4 月 岐阜工業高等 専門学校電気工学科助手, 1988 年 4 月同講師, 1991 年 4 月同助教授, 2001 年 4 月電気情報工 学科教授, 現在に至る。工学博士。主として, 電気絶縁材料の高電界誘電特性と表面撥水性 評価技術の研究に従事。1991 年 電気学会論文 賞受賞。

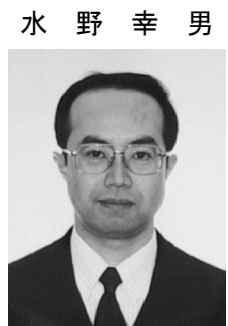

（正員） 1958 年 7 月 8 日生。1986 年 3 月名古 屋大学大学院工学研究科博士後期課程修了。同 年 4 月豊橋技術科学大学電気・電子工学系助手。 1993 年 11 月名古屋工業大学電気情報工学科助 教授, 2003 年 1 月同教授。現在, 同大学大学院 ながれ領域機能工学専攻教授。工学博士。主と して, 極低温電気絶縁, 外部絶縁, 絶縁劣化診 断, 商用周波電界 - 磁界の定量化に関する研究 に従事。低温工学会, IEEE 会員。 


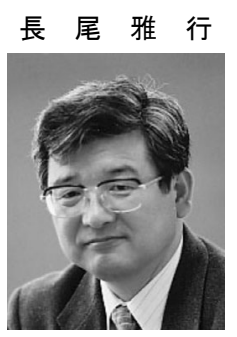

（正員） 1950 年 4 月 16 日生。1978 年 3 月名 古屋大学大学院工学研究科博士後期課程修了。 同大学助手を経て, 1980 年 4 月豊橋技術科学大 学電気・電子光学系講師, 1985 年 4 月同大学助 教授, 1998 年 4 月同大学教授, 現在に至る。1980 年 11 月〜1982 年 7 月, 西ドイッ・アレキサン ダー・フォン・フンボルト財団の援助により, ブラウンシュバイク工科大学にて在外研究 (高 分子の部分放電劣化現象に関する研究)。工学博士。主として, 高 分子の高電界電気物性・絶縁劣化現象に関寸る研究に従事。1991 年電気学会論文賞受賞。応用物理学会, IEEE, CIGRE, 放電学会, 静電気学会, 素材物性学会会員。
小 㟝 正光 (正員) 1939 年 9 月 10 日生。1962 年 3 月名

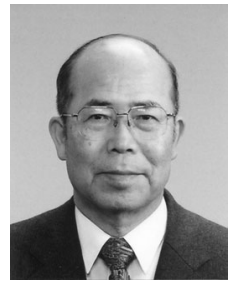
古屋大学工学部電気学科卒業。1966 年 6 月カリ フォルニア大学バークレー校大学院工学研究 科原子核工学専攻修士課程修了。以後, 名古屋 大学工学部助手, 同講師を経て, 1976 年 4 月同 助教授。1979 年 4 月豊橋技術科学大学電気・電 子工学系教授。1998 年 4 月岐阜工業高等専門学 校長。工学博士。主として, 高分子の電気特性, 極低温電気絶縁に関する研究に従事。1979 年, 1991 年電気学会論 文賞受賞。低温工学会, IEEE, CIGRE 会員, IEEE フェロー。 